Article

\title{
Feasibility Investigation for Residential Battery Sizing Considering EV Charging Demand
}

\author{
Noman Shabbir*(D), Lauri Kütt, Kamran Daniel, Victor Astapov, Hadi Ashraf Raja, Muhammad Naveed Iqbal \\ and Oleksandr Husev
}

check for updates

Citation: Shabbir, N.; Kütt, L.; Daniel, K.; Astapov, V.; Raja, H.A.; Iqbal, M.N.; Husev, O. Feasibility Investigation for Residential Battery Sizing Considering EV Charging Demand. Sustainability 2022, 14, 1079. https://doi.org/10.3390/su14031079

Academic Editor: Aritra Ghosh

Received: 15 December 2021

Accepted: 12 January 2022

Published: 18 January 2022

Publisher's Note: MDPI stays neutral with regard to jurisdictional claims in published maps and institutional affiliations.

Copyright: () 2022 by the authors Licensee MDPI, Basel, Switzerland. This article is an open access article distributed under the terms and conditions of the Creative Commons Attribution (CC BY) license (https:// creativecommons.org/licenses/by/ $4.0 /)$.

\author{
Department of Electrical Power Engineering \& Mechatronics, Tallinn University of Technology, \\ 19086 Tallinn, Estonia; lauri.kutt@taltech.ee (L.K.); kdanie@taltech.ee (K.D.); victor.astapov@taltech.ee (V.A.); \\ haraja@taltech.ee (H.A.R.); miqbal@taltech.ee (M.N.I.); oleksandr.husev@taltech.ee (O.H.) \\ * Correspondence: noshab@taltech.ee
}

\begin{abstract}
Photovoltaic (PV) systems along with battery energy storage systems (BESS) are an increasing trend for residential users due to the increasing cost of energy and environmental factors. Future sustainable grids will also have electric vehicles (EVs) integrated into these residential microgrids. However, this large-scale deployment of EVs and PV systems could mean several problems in terms of power quality, hosting capacity and as well economic implications. This paper aims to provide input to more optimal design and management of domestic PV and BESS for residential users with EVs. In this work, a measurement-based data set from a low-voltage distribution network in a rural area has been used. Investigation sees different household and PV-EV penetration levels to propose the BESS capacity and use cases. An economic analysis has been performed to check the feasibility of the proposed systems. The payback period is found to be between 13 to 15 years of the proposed systems.
\end{abstract}

Keywords: photovoltaic systems; electric vehicles charging; battery storage; battery size optimization; economic analysis

\section{Introduction}

Electricity and transportation have been two of the most dominant sectors in the contribution of greenhouse gases [1]. The deployment of renewable energy resources (RES) such as photovoltaics (PV) in electrical grids is growing, and similarly, the usage of electric vehicles (EVs) is also increasing, as these vehicles fall into the category of potentially sustainable and green transposition systems [2-4]. Due to the expected preference for comfortability, it is expected that the users will most often charge their electric vehicles at home. Therefore, the integration of PV and EV in future sustainable distribution grids is of key importance.

PV in conjunction with battery energy storage systems (BESS) is expected to be the most popular RES solution in residential buildings and homes [5]. This system is usually connected to the local grid to reach better utilization for energy produced on-site and, if excessive energy is available from the photovoltaic, then it is sold to the grid. The main purpose is to reduce electric energy costs and obtain benefits by selling energy. However, large-scale photovoltaic and BESS installation can initially be costly, as the cost of photovoltaic is around $400-1000 € / \mathrm{kW}$ while batteries are still around $100 €$ per $\mathrm{kWh}[6,7]$. Therefore, the optimal design of these systems is very important.

The PV generation in residential grids [8-10] and the impact of EV charging on the residential grid have been discussed in [11-14]. While the benefits of PV and EV integration have multiple benefits [15-18], the large-scale PV and EV deployment can also impose extra challenges in the local grids. It is commonly discussed, that large-scale PV deployment with same-time production could mean overloading and overvoltage in the network [19-22]. At 
the same time, the high penetration of electric vehicle loads can cause higher peak loads and thus undervoltage in the network $[23,24]$. The time-wise distance of the PV production peaks, and peak EV domestic charging load could mean cumulation of these issues listed.

A way to mitigate these problems is to include BESS, sized according to the network design parameters and limits. The presence of BESS can ensure that PV energy generated but not utilized on-site is not injected into the grid and this stored energy is used for the charging of EVs. This way residential BESS can directly help to improve demandside management, increase self-consumption, reduce peak load, and reduce photovoltaic consumption in the event of excessive energy generation [25]. One major problem that hinders large-scale installations of the BESS is the initial investment cost, however, it is expected to decrease over the coming years [26].

BESS provides financially and operation-wise optimal results when they are designed closely corresponding to load requirements $[27,28]$. There are several studies available on the optimal use of these BESSs to get maximum benefits. The most popular techniques are linear programming optimization [29-32], genetic algorithm [33], particle swan optimization [34,35], dynamic programming [11,36], convex programming [24,37] and mixed-integer linear programming [38]. Many of the studies listed above used real-time photovoltaic and load data to determine the optimal battery size for maximum reduction in electricity bills.

PV-BESS-EV integration has been investigated for residential users in numerous studies covering aspects of reduction in emissions of using EVs charged from the RES-based residential grid [39] until operational details and structure. In [15,40-43], the architecture, control algorithm, and their economical aspect are covered. The impact of EVs charging from the grid on the network power quality is discussed in [44]. The EV modeling techniques are presented in $[16,45-47]$. The utilization of EV batteries for domestic household load has also been investigated in [48].

The main focus of this study is to investigate the economic feasibility of the PV-BESSEV system and EVs charging loads through it also considers the local market electric energy prices. A residential data set for one year from an Estonian rural grid was taken into consideration along with the PV generation data. The grid consists of eight different domestic users which have been classified as small, medium, and large residential loads. The resolution of the data is one hour. EV charging data is generated using a stochastic model [45]. Finally, the initial economic analysis has been presented. The following are the key points of this paper:

- A PV production-oriented BESS has been proposed for the electrical load and EVs in a residential household and eight different cases of small, medium and large scale have been discussed.

- A linear programming-based battery charging algorithm is used to target minimum annual energy costs by reducing the number of grid usage hours.

- The economic analysis of all the eight household cases with EVs along with variation in the BESS size has also been carried out.

- The payback period for all cases is estimated.

The paper is structured as follows: Section 2 presents residential load data profiles, PV generation data, and EV data used for the context analysis. Section 3 explains the methodology used in this research and gives the economic analysis of the proposed system. Section 4 specifies the results and the corresponding discussion. Finally, the conclusion of this research is presented in Section 5.

\section{Data Profiles}

This section is related to the detailed description of the data used in this study. The recorded residential load and PV energy generation data originate from an Estonian rural grid for a whole year (latitude: 58.2289). The time-resolution of the data was one hour. The EV load profiles are generated based on a stochastic model based on travel activity. 


\subsection{Load Profiles}

The recorder electric load data from the low-voltage distribution network is analyzed in this study. An hourly time-step of measurement was used to collect data in a rural customer for an entire year. Figure 1 illustrates the grid layout and connection topology of the low voltage grid segment under consideration. Eight residential loads are present in this segment, as well as three auxiliary loads (pump station, street lighting, and local small-scale heating plant). These residential electrical load cases constitute a small apartment/flat, medium-size house, and residential apartment building. Table 1 presents the statistical details for all eight cases. Using the measured data profiles, the peak electrical load for a small apartment is between 1 to $4 \mathrm{~kW}$ (Cases 1, 4, 5, 8), for a household is 5 to $6 \mathrm{~kW}$ (Cases $2,5,6$ ) and an apartment building around $37 \mathrm{~kW}$ (Case 3). All these cases are summarized in Table 1 as well as their accumulated annual energy consumption.

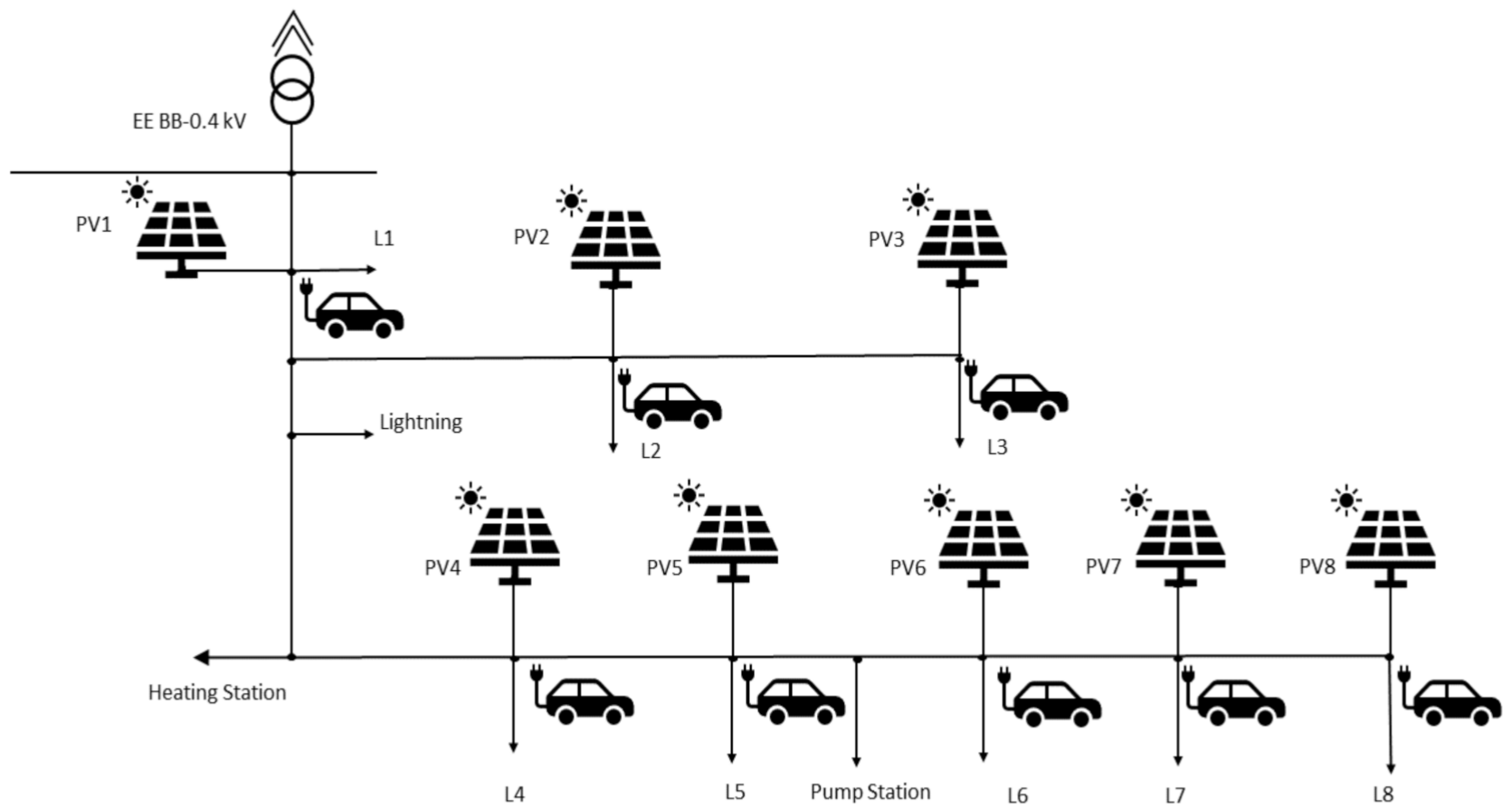

Figure 1. The layout of the low voltage distribution network.

Table 1. Load Profiles of eight different residential users (round up to 0.1).

\begin{tabular}{ccccc}
\hline $\begin{array}{c}\text { Number of } \\
\text { Load }\end{array}$ & $\begin{array}{c}\text { Peak Load } \\
(\mathbf{k W})\end{array}$ & $\begin{array}{c}\text { Average Load } \\
\mathbf{( k W )}\end{array}$ & $\begin{array}{c}\text { Median Load } \\
\mathbf{( k W )}\end{array}$ & $\begin{array}{c}\text { Annual Energy } \\
\text { Consumption } \\
\mathbf{( k W h )}\end{array}$ \\
\hline Case 1 & 1.9 & 0.1 & 0.1 & 741 \\
Case 2 & 5.4 & 1.1 & 0.7 & 9056 \\
Case 3 & 36.7 & 11.9 & 11.1 & 103,842 \\
Case 4 & 2.2 & 0.3 & 0.2 & 2176 \\
Case 5 & 2.7 & 0.3 & 0.2 & 1975 \\
Case 6 & 5.1 & 0.7 & 0.5 & 6482 \\
Case 7 & 5.9 & 0.7 & 0.5 & 6639 \\
Case 8 & 4.1 & 0.4 & 0.3 & 3765 \\
\hline
\end{tabular}

In contrast, the average electrical load is relatively low, e.g., 0.8 to $0.3 \mathrm{~kW}$ in all the small apartments, which is rather low compared to the peak demand. However, for Case 3 , it is around $12 \mathrm{~kW}$ considering a building total. The energy demand for the whole year varies between 700 to $3800 \mathrm{kWh}$ for small apartments, for medium houses, it is varying between 6000 to $9000 \mathrm{kWh}$ and for an apartment building, it is over 100,000 kWh. 


\subsection{PV Profile}

A summer day in (latitude: 58.2289 ) lasts on average over $16 \mathrm{~h}$, while a winter day is down to 4 to $5 \mathrm{~h}$ [22]. In this study, solar PV systems with capacities of $5 \mathrm{~kW}$ have been proposed for a small residence, $10 \mathrm{~kW}$ for medium households, and $20 \mathrm{~kW}$ for a small apartment building. Figure 2 represents the energy output of the $20 \mathrm{~kW}$ PV system for the whole year, scaled from power at the measurement site.

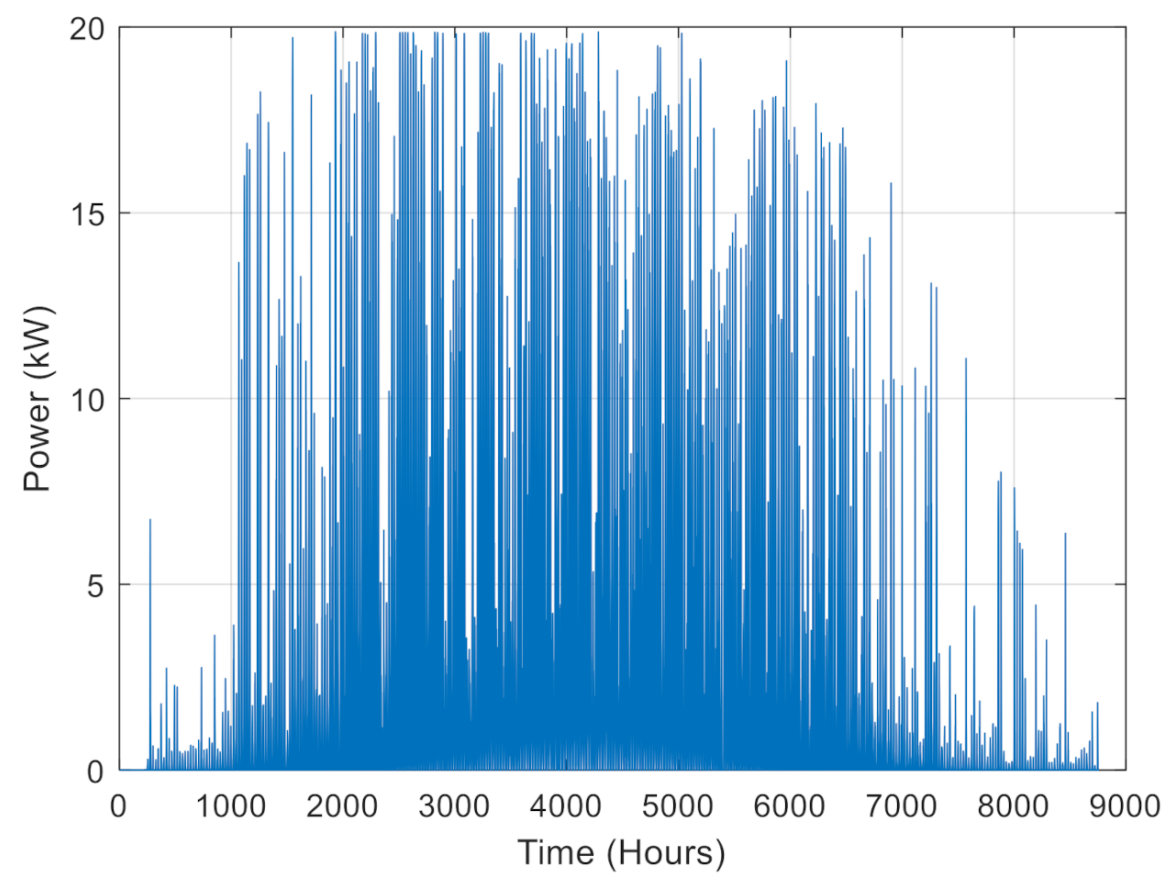

Figure 2. Energy generation from a $20 \mathrm{~kW}$ solar PV.

Based on Figure 2, it is clear that solar energy production is high between March and September and low in the remaining months. As a result, the overall energy generation during these months can be in surplus. The extra energy can be used to charge BESS and EVs as well while the remaining energy can be sold to the grid.

\subsection{EV Profiles}

The EV data used in this study was generated from an EV usage model described in [45]. It is an activity-based model (ABM) that incorporates several socioeconomic factors which influence the travel behavior of an individual. The model generates a travel schedule and based on that, the EV usage pattern is mapped and the load requirements for the grid are defined. The model incorporated a National Traffic Survey (NTS) to obtain information about user travel plans and categorize them. Then the probability distribution is used to define the departure and arrival times for individual trips. Thereafter, the decision is made to charge the battery of the EV or not based on the existing State of Charge (SOC) and the traveling distance. Trips are also classified as work, shopping, school, vacation, business, or any other activity.

In this study, there are eight different domestic household users as defined in Section 2.1. Different numbers of electric vehicles are added to these residential users. These details are shown in Table 2. The number of EVs ranges from 1 to 10. Small apartment and household cases only have one EV and medium load cases have 2 to $4 \mathrm{EVs}$. As Case 3 is a residential apartment building, therefore, $10 \mathrm{EVs}$ are integrated with it. The one-year load profile of case 1, case 2, and case 3 is also shown in Figure 3. The peak loads of cases 1, 2 and 3 are 4.6, 15.4 and $60 \mathrm{~kW}$, respectively. Further details of the other cases are given in Table 3 . 
Table 2. Number of EVs in different households.

\begin{tabular}{cccc}
\hline Number of Load & Number of EVs & Number of Load & Number of EVs \\
\hline Case 1 & 1 & Case 5 & 1 \\
Case 2 & 3 & Case 6 & 2 \\
Case 3 & 10 & Case 7 & 4 \\
Case 4 & 1 & Case 8 & 1 \\
\hline
\end{tabular}
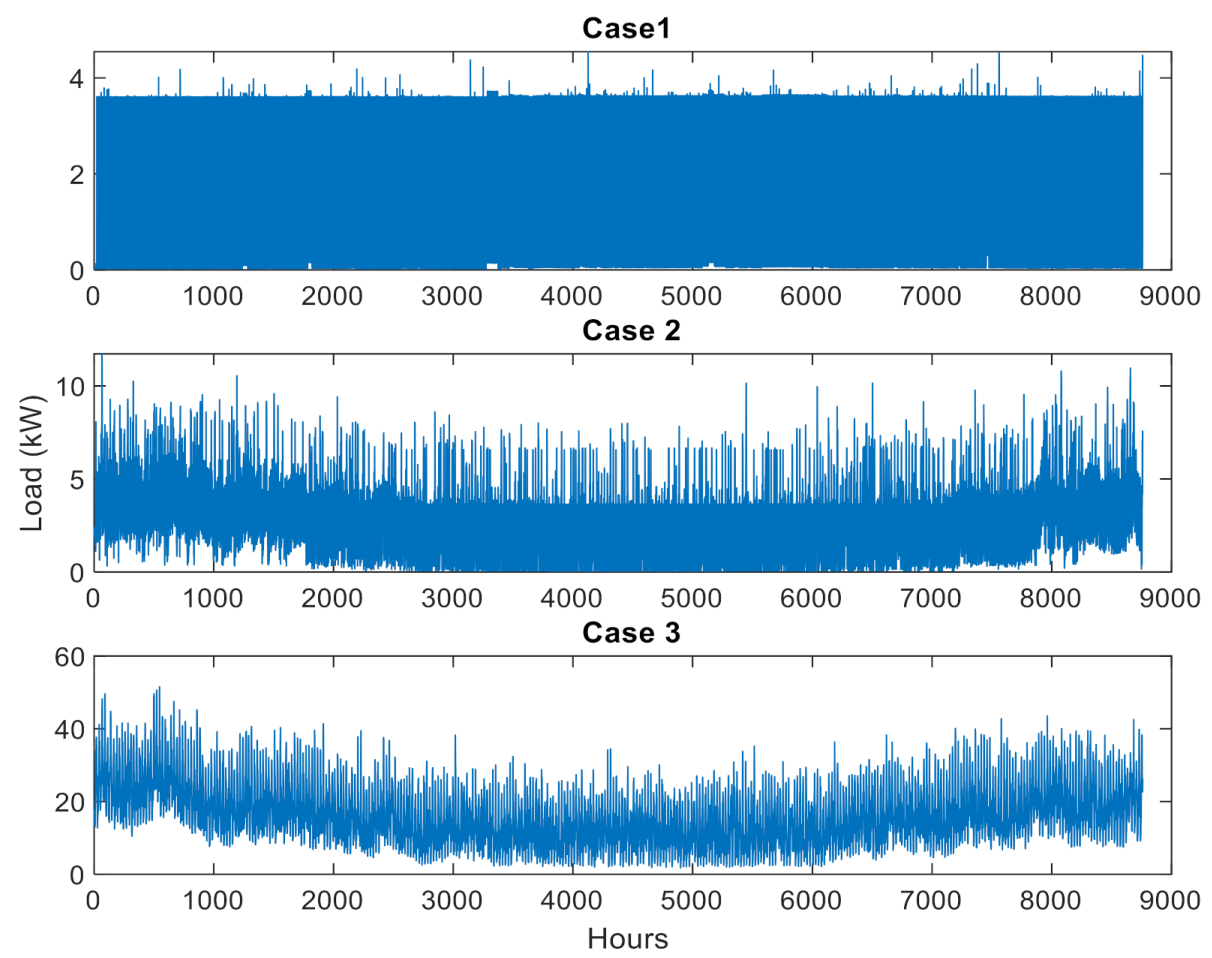

Figure 3. Comparison of small, medium and large scale cases.

Table 3. Load Profiles of eight different residential users with EVs integration.

\begin{tabular}{cccccc}
\hline $\begin{array}{c}\text { Number of } \\
\text { Load }\end{array}$ & $\begin{array}{c}\text { Peak Load } \\
\mathbf{( k W )}\end{array}$ & $\begin{array}{c}\text { Average } \\
\text { Load (kW) }\end{array}$ & $\begin{array}{c}\text { Median } \\
\text { Load (kW) }\end{array}$ & $\begin{array}{c}\text { Annual Energy } \\
\text { Consumption } \\
\mathbf{( k W h )}\end{array}$ & $\begin{array}{c}\text { Installed PV } \\
\text { Power (kW) }\end{array}$ \\
\hline Case 1 & 4.6 & 0.8 & 0.1 & 7250 & 5 \\
Case 2 & 15.4 & 2.9 & 2.6 & 25,800 & 10 \\
Case 3 & 60 & 16.4 & 15.4 & 143,725 & 20 \\
Case 4 & 5.7 & 0.9 & 0.3 & 8686 & 5 \\
Case 5 & 6.2 & 0.9 & 0.2 & 8485 & 5 \\
Case 6 & 15.2 & 2.3 & 1.2 & 20,450 & 10 \\
Case 7 & 16 & 2.3 & 1.7 & 20,610 & 10 \\
Case 8 & 7.9 & 1.8 & 0.4 & 10,270 & 5 \\
\hline
\end{tabular}

\section{Methodology}

\subsection{Battery Energy Storage System (BESS)}

In recent years, much effort and research have been put into battery storage technologies such as PV-based storage systems, electrical vehicles, and portable devices [24]. Over the years, research in battery technology and bulk generation has drastically reduced the prices and size of batteries [6]. This has resulted in the modern commonly used batteries of Nickel Manganese Cobalt Oxide (NMC) and Lithium-Ion(Li-ion) batteries [49]. Currently, the cost of a new battery is estimated to be around $100 €$ per $\mathrm{kWh}$. It is also estimated that with advancements in technology and recent studies, the life cycle of batteries will be around 20 years [50]. 
Currently, Li-ion batteries are the widely used batteries in conjunction with BESS installed with solar PV systems. These are preferred mostly due to their compact size, lack of maintenance, and higher efficiency, roughly more than $85 \%$ [51]. However, due to their charge/recharge cycles, the practical life of these Li-ion batteries is estimated to be around 5 years [52]. This is not feasible and challenging as the payback period for these Li-ion batteries is not economically viable within 5 years. Therefore, these Li-ion battery installations in conjunction with PV-based BESS systems are often supported by government incentives in terms of reduced tariffs and subsidies [38]. However, to further minimize operational costs, it is still needed to calculate the optimal battery size. This includes several configurable parameters for the BESS system, which are shown in Table 4 for each case.

Table 4. Parameters of the BESS.

\begin{tabular}{cc}
\hline Number of Load & $\begin{array}{c}\text { Battery Capacity } \\
\text { (kWh) }\end{array}$ \\
\hline Case 1 & 4 \\
Case 2 & 41 \\
Case 3 & 548 \\
Case 4 & 10 \\
Case 5 & 10 \\
Case 6 & 35 \\
Case 7 & 35 \\
Case 8 & 20 \\
\hline
\end{tabular}

The algorithm designed for charging and discharging PV-based BESS systems and calculating battery size is shown in Figure 4 . The algorithm is designed with the optimal electric energy price value target and BESS charging is only done when it is needed and the electric energy price is low. Whereas when the cost of electricity is high, batteries can be discharged to inject power into the grid and be used for in-household purposes to keep the cost of energy to a minimum. Further details of the algorithm can be found in $[53,54]$.

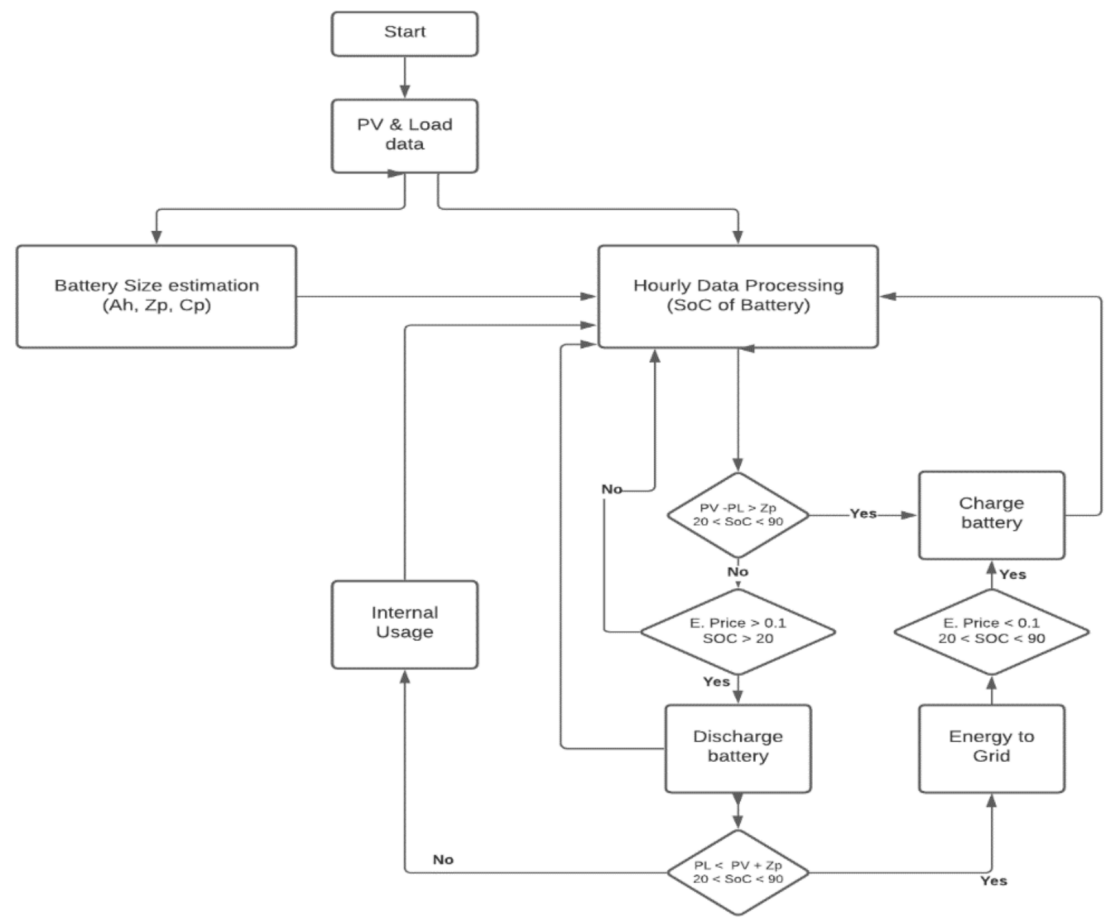

Figure 4. The flowchart of the proposed algorithm. 
The impact on grid usage in terms of hours based on the designed algorithm for each case is shown in Table 5. The number of hours ' $j$ ' describes the total number of hours of grid utilization in one year. The impact of battery size variation is also shown; it can be seen that with the increase in battery size, the hours of power drawn from the grid have reduced. The number of hours reduced vary for each case according to the scenarios as; in case 7 , the system with $50 \%$ battery size is already enough, so increasing the battery size will not improve it any further. Therefore, it is also essential to calculate the optimal and economical battery size for the implemented PV-based BESS systems.

Table 5. BESS size variation and impact on grid use.

\begin{tabular}{|c|c|c|c|c|c|c|}
\hline $\begin{array}{l}\text { Number } \\
\text { of Load }\end{array}$ & $\begin{array}{c}\text { Battery } \\
\text { Size }(\%)\end{array}$ & $\underset{\text { (hour) }}{\mathbf{j}}$ & $\begin{array}{c}\text { a } \\
\text { (hours) }\end{array}$ & $\begin{array}{c}\text { b } \\
\text { (hours) }\end{array}$ & $\begin{array}{c}\text { c } \\
\text { (hours) }\end{array}$ & $\begin{array}{c}\mathrm{d} \\
\text { (hours) }\end{array}$ \\
\hline \multirow{3}{*}{ Case 1} & 50 & 2051 & 3040 & 292 & 286 & 3663 \\
\hline & 100 & 1456 & 3139 & 400 & 248 & 4013 \\
\hline & 200 & 1237 & 3171 & 473 & 241 & 4120 \\
\hline \multirow{3}{*}{ Case 2} & 50 & 3740 & 1616 & 248 & 395 & 3551 \\
\hline & 100 & 3441 & 1701 & 310 & 441 & 3749 \\
\hline & 200 & 3125 & 1742 & 359 & 524 & 4058 \\
\hline \multirow{3}{*}{ Case 3} & 50 & 3764 & 1690 & 227 & 416 & 3495 \\
\hline & 50 & 3622 & 1002 & 96 & 489 & 4529 \\
\hline & 100 & 3214 & 1035 & 156 & 614 & 4969 \\
\hline \multirow{3}{*}{ Case 4} & 200 & 2776 & 1035 & 205 & 769 & 5513 \\
\hline & 100 & 2542 & 2400 & 335 & 383 & 3866 \\
\hline & 200 & 2178 & 2449 & 367 & 411 & 4177 \\
\hline \multirow{3}{*}{ Case 5} & 50 & 2720 & 2372 & 254 & 330 & 3744 \\
\hline & 100 & 2082 & 2495 & 344 & 320 & 4159 \\
\hline & 200 & 1724 & 2538 & 401 & 342 & 4439 \\
\hline \multirow{3}{*}{ Case 6} & 50 & 3083 & 2002 & 261 & 347 & 3761 \\
\hline & 100 & 2580 & 2173 & 341 & 347 & 4013 \\
\hline & 200 & 2231 & 2243 & 382 & 401 & 4305 \\
\hline \multirow{3}{*}{ Case 7} & 50 & 2922 & 1770 & 242 & 305 & 4131 \\
\hline & 100 & 2490 & 1879 & 322 & 347 & 4416 \\
\hline & 200 & 2084 & 1942 & 372 & 394 & 4756 \\
\hline \multirow{3}{*}{ Case 8} & 50 & 2970 & 1818 & 273 & 349 & 4048 \\
\hline & 100 & 2365 & 1999 & 338 & 352 & 4410 \\
\hline & 200 & 2001 & 2059 & 381 & 400 & 4719 \\
\hline
\end{tabular}

$\mathrm{j}=$ no. of hours of grid usage, $\mathrm{a}=\mathrm{PV}$ usage hours, $\mathrm{b}=$ Battery discharging hours to the grid, $\mathrm{c}=$ Battery charging hours from grid, $\mathrm{d}=$ Batter discharging hours for on-site usage.

Similarly, the peak power drawn from the grid and injected into the grid by the PVbased BESS systems in each case is shown in Table 6. The table states the value for each season of the year, and a comparison can be made to see the difference between different seasons according to different battery sizes. It can be seen in Table 8 that the peak power drawn from the grid and injected into the grid are not much different in the case of case 1 and case 4 . Even for different battery sizes, both cases have net negative energy, which states that the minimum battery size considered here is more than sufficient for those two cases. Whereas in the scenario of case 3, the battery sizes and PV power rating are still far from enough to reduce the difference significantly. Different scenarios for case 3 will be further discussed in the later section. 
Table 6. Peak loads in the dependent season and variable BESS sizes.

\begin{tabular}{|c|c|c|c|c|c|c|c|c|c|c|}
\hline \multirow[t]{2}{*}{$\begin{array}{c}\text { Number of } \\
\text { Load }\end{array}$} & \multirow[t]{2}{*}{$\begin{array}{c}\text { Battery Size } \\
(\%)\end{array}$} & \multicolumn{5}{|c|}{$\begin{array}{c}\text { Peak Power Drawn from Grid } \\
(\mathbf{k W})\end{array}$} & \multicolumn{4}{|c|}{$\begin{array}{l}\text { Peak Power Injected into the Grid } \\
\qquad(\mathrm{kW})\end{array}$} \\
\hline & & Wt. & Sp. & Sum. & Aut. & Wt. & Sp. & Sum. & Aut. & Wt. \\
\hline \multirow{4}{*}{ Case 1} & 50 & 4.5 & 4.83 & 4.5 & 3.9 & 4.3 & -4.9 & -4.9 & -4.7 & 4.5 \\
\hline & 100 & 4.5 & 4.83 & 4.5 & 3.9 & 4.2 & -4.9 & -4.9 & -4.7 & 4.5 \\
\hline & 200 & 4.5 & 4.37 & 4.2 & 3.8 & 4.2 & -4.9 & -4.9 & -4.7 & 4.5 \\
\hline & 50 & 13.7 & 9.1 & 10 & 10 & 12.7 & -9.7 & -9.9 & -9.6 & 13.4 \\
\hline \multirow[t]{3}{*}{ Case 2} & 100 & 13.7 & 9.7 & 10 & 11.9 & 12.8 & -9.7 & -9.9 & -9.4 & 13.4 \\
\hline & 200 & 13.7 & 9.6 & 10 & 10 & 12.8 & -9.7 & -9.9 & -9.4 & 13.4 \\
\hline & 50 & 115.8 & 113.7 & 99.1 & 40.1 & 110 & -75.2 & -76.6 & -73.6 & 115.5 \\
\hline \multirow[t]{3}{*}{ Case 3} & 100 & 116.8 & 113.3 & 99.1 & 40.1 & 110 & -75.2 & -76.6 & -75.5 & 116.7 \\
\hline & 200 & 113.7 & 113.3 & 99.1 & 40.1 & 110 & -75.2 & -76.6 & -75.5 & 113.6 \\
\hline & 50 & 4.8 & 4.5 & 4.7 & 4.3 & 4.7 & -4.9 & -4.9 & -4.4 & 4.8 \\
\hline \multirow[t]{3}{*}{ Case 4} & 100 & 4.8 & 4.5 & 4.7 & 4.3 & 4.7 & -4.9 & -4.9 & -4.6 & 4.8 \\
\hline & 200 & 4.8 & 3.7 & 4.6 & 4.8 & 4.7 & -4.9 & -4.9 & -4.6 & 4.8 \\
\hline & 50 & 4.8 & 4.3 & 4.3 & 3.9 & 4.4 & -4.8 & -4.8 & -4.6 & 4.8 \\
\hline \multirow[t]{3}{*}{ Case 5} & 100 & 4.8 & 4.2 & 4.2 & 3.9 & 4.4 & -4.8 & -4.8 & -4.6 & 4.8 \\
\hline & 200 & 51 & 3.6 & 4.2 & 3.7 & 4.4 & -4.8 & -4.8 & -4.6 & 5 \\
\hline & 50 & 14.2 & 12 & 11.7 & 12.6 & 13.4 & -9.6 & -9.6 & -8.6 & 14.2 \\
\hline \multirow[t]{3}{*}{ Case 6} & 100 & 14.2 & 12 & 11.7 & 12.6 & 13.4 & -9.6 & -9.6 & -8.6 & 14.2 \\
\hline & 200 & 14.2 & 12 & 11.7 & 12.6 & 13.4 & -9.6 & -9.6 & -8.6 & 14.2 \\
\hline & 50 & 13.8 & 11.7 & 12.5 & 12.5 & 12.6 & -9.7 & -9.7 & -8.8 & 13.8 \\
\hline \multirow[t]{3}{*}{ Case 7} & 100 & 13.8 & 11.7 & 12.5 & 12.5 & 12.6 & -9.7 & -9.7 & -8.8 & 13.8 \\
\hline & 200 & 13.8 & 11.7 & 12.5 & 12.5 & 12.6 & -9.7 & -9.7 & -8.8 & 13.8 \\
\hline & 50 & 6.5 & 5.74 & 5.3 & 5.4 & 5.63 & -4.8 & -4.8 & -4.6 & 6.5 \\
\hline \multirow{2}{*}{ Case 8} & 100 & 6.5 & 5.78 & 5.8 & 5.4 & 5.63 & -4.8 & -4.8 & -4.6 & 6.5 \\
\hline & 200 & 6.5 & 5.78 & 5.8 & 5.4 & 5.63 & -4.8 & -4.8 & -4.6 & 6.5 \\
\hline
\end{tabular}

\subsection{Economic Analysis}

The energy management system has to be financially sound to motivate the implementation of the nZEB system. Here we evaluate the PV-based BESS design for the eight different load cases. Economic analysis for PV-based systems depends on several parameters, which are discussed in detail. This section will discuss the economic analysis of all 8 cases, along with the impact of the PV-based BESS system on the grid.

The electricity price on the electric energy stock market is provided with hourly steps. For this reason, the observation time step considered in this study is also $1 \mathrm{~h}$. Currently, the price for a battery suitable for the BESS is around $100 € / \mathrm{kWh}$ whereas, for PV, it is around $400 € / \mathrm{kW}$ [55]. Table 7 shows the economic analysis for all 8 cases at different battery sizes. As it can be seen that in all cases, the cost of electricity is significantly reduced after integrating PV-BESS based system.

Table 7. Battery estimates and net energy cost for the year.

\begin{tabular}{cccc}
\hline Number of Load & Battery Size (\%) & $\begin{array}{c}\text { Accumulated Cost of } \\
\text { Energy from the Grid (€) }\end{array}$ & $\begin{array}{c}\text { Accumulated Cost } \\
\text { with PV-BESS-EV (€) }\end{array}$ \\
\hline \multirow{3}{*}{ Case 1} & 50 & 200 & -35.0 \\
& 100 & 200 & -45.0 \\
Case 2 & 200 & 200 & -56.6 \\
& 50 & 793 & 289 \\
& 100 & 793 & 270 \\
Case 3 & 200 & 793 & 242 \\
& 50 & 5237 & 3556 \\
& 100 & 5237 & 3130 \\
& 200 & 5237 & 2565 \\
& 50 & 246 & -4.4 \\
\hline
\end{tabular}


Table 7. Cont.

\begin{tabular}{|c|c|c|c|}
\hline Number of Load & Battery Size (\%) & $\begin{array}{l}\text { Accumulated Cost of } \\
\text { Energy from the Grid }(€)\end{array}$ & $\begin{array}{c}\text { Accumulated Cost } \\
\text { with PV-BESS-EV (€) }\end{array}$ \\
\hline \multirow[t]{3}{*}{ Case 4} & 100 & 246 & -16 \\
\hline & 200 & 246 & -30 \\
\hline & 50 & 245 & -5.3 \\
\hline \multirow{3}{*}{ Case 5} & 100 & 245 & -17 \\
\hline & 200 & 245 & -31 \\
\hline & 50 & 546 & 40.2 \\
\hline \multirow[t]{3}{*}{ Case 6} & 100 & 546 & 33.2 \\
\hline & 200 & 546 & 16.1 \\
\hline & 50 & 875 & 374.2 \\
\hline \multirow[t]{3}{*}{ Case 7} & 100 & 875 & 360.8 \\
\hline & 200 & 875 & 344.3 \\
\hline & 50 & 314 & 54 \\
\hline \multirow[t]{2}{*}{ Case 8} & 100 & 314 & 50 \\
\hline & 200 & 314 & 41 \\
\hline
\end{tabular}

The net usage of the prices after the integration of the BESS system has gone negative in Case 1, regardless of the battery size. In comparison, it has reduced by approximately $50-90 \%$ in other cases. In most cases, this decrease is quite significant, whereas in Case 3, it is only up to around $50 \%$, which could be due to insufficient PV power and battery size. This is discussed in more detail in the next section.

\section{Discussion}

As shown in Table 7, the net prices for electricity usage with a BESS system result in a drastic decrease other than case 3, where the price is still high even if it is decreased. Case 3 is further taken into account and different power PV systems are implemented in case 3 to get the relevant study. This also proves that the optimal solution for a specific case can be achieved by increasing PV or varying battery size and the net energy cost can be reduced significantly. In Table 8, results are shown for two scenarios where the PV power is increased to $40 \mathrm{~kW}$ and $60 \mathrm{~kW}$. Net energy cost is also calculated for different battery sizes in each case.

Table 8. Parameters for Case 3 with increased PV ratings.

\begin{tabular}{cccccccc}
\hline $\begin{array}{c}\text { Rated PV } \\
\text { Power (kW) }\end{array}$ & $\begin{array}{c}\text { Battery Size } \\
\mathbf{( \% )}\end{array}$ & j (hours) & $\begin{array}{c}\mathbf{a} \\
\text { (hours) }\end{array}$ & $\begin{array}{c}\mathbf{b} \\
\text { (hours) }\end{array}$ & $\begin{array}{c}\mathbf{c} \\
\text { (hours) }\end{array}$ & $\begin{array}{c}\text { d } \\
\text { (hours) }\end{array}$ & $\begin{array}{c}\text { Net Energy } \\
\text { Cost (€) }\end{array}$ \\
\hline \multirow{2}{*}{40} & 50 & 4131 & 1269 & 102 & 552 & 3810 & 2557.3 \\
& 100 & 3505 & 1543 & 151 & 617 & 4178 & 2256.8 \\
& 200 & 3151 & 1580 & 189 & 786 & 4626 & 1636.1 \\
60 & 50 & 4088 & 1338 & 143 & 522 & 3713 & 1617.2 \\
& 100 & 3314 & 1662 & 194 & 535 & 4125 & 1456 \\
\hline
\end{tabular}

As shown from Table 10, the net energy cost for most cases also decreases per the increased power by increasing PV power. In the case where PV power is $100 \mathrm{~kW}$, the net energy cost goes negative. This shows that a good PV power source and a good battery size should be selected for each case. Peak voltage variations for case 3 are also calculated for each season with the increased PV power and battery size and are shown in Table 9. 
Table 9. Peak load variations for case 3 with increased PV ratings.

\begin{tabular}{cccccccccc}
\hline $\begin{array}{c}\text { Rated PV } \\
\text { Power (kW) }\end{array}$ & $\begin{array}{c}\text { Battery Size } \\
(\%)\end{array}$ & \multicolumn{3}{c}{ Peak Power Drawn from Grid (kW) } & \multicolumn{3}{c}{ Peak Power Injected into the Grid (kW) } \\
\hline & & Wt. & Sp. & Sum. & Aut. & Wt. & Sp. & Sum. & Aut. \\
\hline & 50 & 113.9 & 113.3 & 99.1 & 40.1 & 110 & -106.6 & -112.1 & -103 \\
40 & 100 & 115.8 & 113.3 & 99.1 & 40.1 & 110 & -73.5 & -104.1 & -77.4 \\
& 200 & 113.7 & 106.6 & 99.1 & 40.1 & 110 & -73.5 & -76.7 & -77.4 \\
& 50 & 113.7 & 102.6 & 99.1 & 40.1 & 110 & -111.9 & -131.7 & -113.4 \\
60 & 100 & 115.5 & 109.8 & 95.6 & 40.1 & 110 & -126.3 & -131.6 & -110.9 \\
& 200 & 116.7 & 106.5 & 95.6 & 40.1 & 110 & -126.3 & -128.1 & -76.7 \\
\hline
\end{tabular}

From Table 9, it can be stated that the power injected into the grid increases with an increase in PV power, while the increase in battery size does not make much of a positive difference. For different seasons, the power drawn from the grid varies according to consumption, but the power injected into the grid is overpowering the drawn power with an increase in PV power. This also has a positive impact on the grid, as surplus power can be utilized elsewhere. The payback period for PV is calculated and shown in Table 10.

Table 10. Payback periods for different BESS sizes.

\begin{tabular}{|c|c|c|c|c|c|c|}
\hline $\begin{array}{c}\text { Number of } \\
\text { Load }\end{array}$ & Battery Size (\%) & $\begin{array}{c}\text { PV Rated } \\
\text { Power }(k W)\end{array}$ & $\begin{array}{l}\text { Cost of PV and } \\
\text { Inverter }(€)\end{array}$ & $\begin{array}{l}\text { Cost of } \\
\text { BESS (€) }\end{array}$ & $\begin{array}{l}\text { Total Savings } \\
\text { per Years }(€)\end{array}$ & $\begin{array}{c}\text { Payback } \\
\text { Period (years) }\end{array}$ \\
\hline \multirow{5}{*}{ Case 1} & 50 & 5 & 3000 & 200 & 235 & 14 \\
\hline & 100 & 5 & 3000 & 400 & 245 & 14 \\
\hline & 200 & 5 & 3000 & 800 & 256 & 15 \\
\hline & No EV (BESS 100\%) & 5 & 3000 & 400 & 245 & 14 \\
\hline & No BESS & 5 & 3000 & - & 241 & 12 \\
\hline \multirow{5}{*}{ Case 2} & 50 & 10 & 6000 & 2100 & 506 & 16 \\
\hline & 100 & 10 & 6000 & 4100 & 524 & 19 \\
\hline & 200 & 10 & 6000 & 8100 & 552 & 26 \\
\hline & No EV (BESS 100\%) & 10 & 6000 & 4100 & 472 & 16 \\
\hline & No BESS & 10 & 6000 & - & 472 & 13 \\
\hline \multirow{5}{*}{ Case 3} & 50 & 20 & 12,000 & 27,500 & 1680 & 24 \\
\hline & 100 & 20 & 12,000 & 54,900 & 2107 & 32 \\
\hline & 200 & 20 & 12,000 & 109,800 & 2672 & 46 \\
\hline & No EV (BESS 100\%) & 20 & 12,000 & 54,900 & 954 & 20 \\
\hline & No BESS & 20 & 12,000 & - & 954 & 13 \\
\hline \multirow{5}{*}{ Case 4} & 50 & 5 & 3000 & 500 & 250 & 14 \\
\hline & 100 & 5 & 3000 & 1000 & 262 & 15 \\
\hline & 200 & 5 & 3000 & 2000 & 275 & 18 \\
\hline & No EV (BESS 100\%) & 5 & 3000 & 1000 & 241 & 13 \\
\hline & No BESS & 5 & 3000 & - & 241 & 12 \\
\hline \multirow{5}{*}{ Case 5} & 50 & 5 & 3000 & 500 & 250 & 14 \\
\hline & 100 & 5 & 3000 & 1000 & 261 & 15 \\
\hline & 200 & 5 & 3000 & 2000 & 275 & 18 \\
\hline & No EV (BESS 100\%) & 5 & 3000 & 1000 & 241 & 13 \\
\hline & No BESS & 5 & 3000 & - & 241 & 12 \\
\hline \multirow{5}{*}{ Case 6} & 50 & 10 & 6000 & 1800 & 506 & 15 \\
\hline & 100 & 10 & 6000 & 3500 & 513 & 19 \\
\hline & 200 & 10 & 6000 & 7000 & 530 & 25 \\
\hline & No EV (BESS 100\%) & 10 & 6000 & 3500 & 513 & 14 \\
\hline & No BESS & 10 & 6000 & - & 472 & 15 \\
\hline
\end{tabular}


Table 10. Cont.

\begin{tabular}{|c|c|c|c|c|c|c|}
\hline $\begin{array}{l}\text { Number of } \\
\text { Load }\end{array}$ & Battery Size (\%) & $\begin{array}{c}\text { PV Rated } \\
\text { Power }(\mathbf{k W})\end{array}$ & $\begin{array}{l}\text { Cost of PV and } \\
\text { Inverter }(€)\end{array}$ & $\begin{array}{c}\text { Cost of } \\
\text { BESS }(€)\end{array}$ & $\begin{array}{l}\text { Total Savings } \\
\text { per Years }(€)\end{array}$ & $\begin{array}{c}\text { Payback } \\
\text { Period (years) }\end{array}$ \\
\hline \multirow{5}{*}{ Case 7} & 50 & 10 & 6000 & 1800 & 506 & 15 \\
\hline & 100 & 10 & 6000 & 3500 & 500 & 19 \\
\hline & 200 & 10 & 6000 & 7000 & 514 & 25 \\
\hline & No EV (BESS 100\%) & 10 & 6000 & 3500 & 514 & 14 \\
\hline & No BESS & 10 & 6000 & - & 472 & 13 \\
\hline \multirow{5}{*}{ Case 8} & 50 & 5 & 3000 & 1000 & 260 & 15 \\
\hline & 100 & 5 & 3000 & 2000 & 264 & 19 \\
\hline & 200 & 5 & 3000 & 4000 & 272 & 26 \\
\hline & No EV (BESS 100\%) & 5 & 3000 & 2000 & 264 & 14 \\
\hline & No BESS & 5 & 3000 & - & 241 & 12 \\
\hline
\end{tabular}

The payback period of PV and BESS integrated systems varies according to the implemented PV power rating. Therefore, the payback period varies from 13 years to 40 years, depending on the case and the PV-BESS system implemented. On average, the payback period is around 13-15 years for each case depending on the BESS size variation, whereas the specific payback periods can be seen from the table. The repayment period is calculated based on the units saved plus the current electricity price in Estonia, which may vary with time in the future, so this can be referred to as a rough estimate.

\section{Conclusions}

Worldwide use of electric vehicles will continue to increase in the coming years. On the other hand, the load of EVs is high and they require more energy from the grid as compared to other residential loads. Therefore, a PV-BESS and EV integrated system can be a feasible, green, and more economical solution. However, the initial cost of the PV-BESS system and the PQ issues generated by the higher number of PV-BESS-EV integration needs some solution as well.

This paper concerns the economical and feasibility study of these integrated PV-BESSEV systems for residential users. The real-time residential load and PV data were used from an Estonian distribution network, and EV load profiles generated via travel activity-based stochastic modeling were added. The main aim here was to minimize the dependency on the local electrical grid. Then the BESS size for these residential users was calculated and a control algorithm was implemented to charge or discharge the BESS depending on the load and availability of the PV energy. Moreover, the BESS size was also varied to find the optimal economic numbers and the payback period. The payback period is around $13-15$ years.

The results indicate that the proposed method gives a significant reduction in energy bills and in one case the user will even earn money by selling extra energy to the grid. Two cases have a nearly zero balance thus fulfilling the criteria of nZEBs. The other cases also showed a significant drop in electricity bills varying from 45 to $80 \%$.

For future work, the proposed energy management scheme can be implemented in a real-time small residential network to measure the accuracy of the results. Moreover, it can be extended to a bigger network and its feasibility and payback periods can be determined.

Author Contributions: Conceptualization, N.S. and L.K.; methodology, N.S. \& L.K.; software, N.S. \& H.A.R.; validation, H.A.R. and K.D.; formal analysis, M.N.I.; investigation, V.A. \& O.H.; data curation, M.N.I. \& V.A.; writing—original draft preparation, N.S.; writing—review and editing, L.K. \& O.H.; visualization, H.A.R. \& K.D.; supervision, L.K. \& O.H.; project administration, L.K., O.H.; funding acquisition, L.K. All authors have read and agreed to the published version of the manuscript.

Funding: This work was supported by Estonian Research Council grants PSG142, PRG675 and PSG 739.

Institutional Review Board Statement: Not applicable. 
Informed Consent Statement: Not applicable.

Data Availability Statement: Not applicable.

Conflicts of Interest: The authors declare that they have no conflict of interest.

\section{References}

1. European Environment Agency (EEA) Climate Change. Camb. Univ. Press 2019, 53, 1689-1699. [CrossRef]

2. Fachrizal, R.; Ramadhani, U.H.; Munkhammar, J.; Widén, J. Combined PV-EV hosting capacity assessment for a residential LV distribution grid with smart EV charging and PV curtailment. Sustain. Energy Grids Netw. 2021, 26, 100445. [CrossRef]

3. Ioannis, L.; Alskaif, T.; Coccato, S.; van Sark, W.; Schram, E.B.W. Review of Energy in the Built Environment. Smart Cities 2020, 3 , 248-288.

4. IEA. In 2017 Global Outlook EV Electric Vehicles; IEA: Paris, France, 2017.

5. Khezri, R.; Mahmoudi, A.; Aki, H. Optimal planning of solar photovoltaic and battery storage systems for grid-connected residential sector: Review, challenges and new perspectives. Renew. Sustain. Energy Rev. 2022, 153, 111763. [CrossRef]

6. Ahmadiahangar, R.; Husev, O.; Blinov, A.; Karami, H.; Rosin, A. Development of a Battery Sizing Tool for Nearly Zero Energy Buildings. IECON Proc. 2020, 2020, 5149-5154. [CrossRef]

7. Georgiou, G.S.; Christodoulides, P.; Kalogirou, S.A. Optimizing the energy storage schedule of a battery in a PV grid- connected nZEB using linear programming. Energy 2020, 208, 118177. [CrossRef]

8. Shabbir, N.; Usman, M.; Jawad, M.; Zafar, M.H.; Iqbal, M.N.; Kütt, L. Economic analysis and impact on national grid by domestic photovoltaic system installations in Pakistan. Renew. Energy 2020, 153, 509-521. [CrossRef]

9. Luthander, R.; Lingfors, D.; Widén, J. Large-scale integration of photovoltaic power in a distribution grid using power curtailment and energy storage. Sol. Energy 2017, 155, 1319-1325. [CrossRef]

10. Papaioannou, I.T.; Alexiadis, M.C.; Demoulias, C.S.; Labridis, D.P.; Dokopoulos, P.S. Modeling and field measurements of photovoltaic units connected to LV grid. Study of penetration scenarios. IEEE Trans. Power Deliv. 2011, 26, 979-987. [CrossRef]

11. Dubey, A.; Santoso, S. Electric Vehicle Charging on Residential Distribution Systems: Impacts and Mitigations. IEEE Access 2015, 3, 1871-1893. [CrossRef]

12. Johansson, S.; Persson, J.; Lazarou, S.; Theocharis, A. Investigation of the impact of large-scale integration of electric vehicles for a Swedish distribution network. Energies 2019, 12, 4717. [CrossRef]

13. Leemput, N.; Geth, F.; Van Roy, J.; Delnooz, A.; Buscher, J.; Driesen, J. Impact of electric vehicle on-board single-phase charging strategies on a flemish residential grid. IEEE Trans. Smart Grid 2014, 5, 1815-1822. [CrossRef]

14. Luthander, R.; Shepero, M.; Munkhammar, J.; Widén, J. Photovoltaics and opportunistic electric vehicle charging in the power system-A case study on a Swedish distribution grid. IET Renew. Power Gener. 2019, 13, 710-716. [CrossRef]

15. Shepero, M.; Munkhammar, J.; Widén, J.; Bishop, J.D.K.; Boström, T. Modeling of photovoltaic power generation and electric vehicles charging on city-scale: A review. Renew. Sustain. Energy Rev. 2018, 89, 61-71. [CrossRef]

16. Richardson, D.B. Electric vehicles and the electric grid: A review of modeling approaches, Impacts, and renewable energy integration. Renew. Sustain. Energy Rev. 2013, 19, 247-254. [CrossRef]

17. Mwasilu, F.; Justo, J.J.; Kim, E.K.; Do, T.D.; Jung, J.W. Electric vehicles and smart grid interaction: A review on vehicle to grid and renewable energy sources integration. Renew. Sustain. Energy Rev. 2014, 34, 501-516. [CrossRef]

18. Liu, L.; Kong, F.; Liu, X.; Peng, Y.; Wang, Q. A review on electric vehicles interacting with renewable energy in smart grid. Renew. Sustain. Energy Rev. 2015, 51, 648-661. [CrossRef]

19. Denholm, P.; O'Connell, M.; Brinkman, G.; Jorgenson, J. Overgeneration from Solar Energy in California: A Field Guide to the Duck Chart (NREL/TP-6A20-65023). Tech. Rep. 2015, 1-46.

20. Shafiq, M.; Kutt, L.; Lehtonen, M.; Nieminen, T.; Hashmi, M. Parameters identification and modeling of high-frequency current transducer for partial discharge measurements. IEEE Sens. J. 2013, 13, 1081-1091. [CrossRef]

21. Ali, A.; Mahmoud, K.; Lehtonen, M. International Journal of Electrical Power and Energy Systems Maximizing Hosting Capacity of Uncertain Photovoltaics by Coordinated Management of OLTC, VAr Sources and Stochastic EVs. Int. J. Electr. Power Energy Syst. 2021, 127, 106627. [CrossRef]

22. Vinnal, T.; Puusepp, H.; Shabbir, N.; Iqbal, N. Case study of non-linear PV inverter devices attached to the LV distribution network. Agron. Res. 2020, 18, 2639-2652.

23. Guo, C.; Zhu, K.; Chen, C.; Xiao, X. Characteristics and effect laws of the large-scale electric Vehicle's charging load. eTransportation 2020, 3, 100049. [CrossRef]

24. Jawad, M.; Qureshi, M.B.; Ali, S.M.; Shabbir, N.; Khan, M.U.; Aloraini, A.; Nawaz, R. A cost-effective electric vehicle intelligent charge scheduling method for commercial smart parking lots using a simplified convex relaxation technique. Sensors 2020, 20, 4842. [CrossRef] [PubMed]

25. Parra, D.; Patel, M.K. The nature of combining energy storage applications for residential battery technology. Appl. Energy 2019, 239, 1343-1355. [CrossRef]

26. Mulleriyawage, U.G.K.; Shen, W.X. Optimally sizing of battery energy storage capacity by operational optimization of residential PV-Battery systems: An Australian household case study. Renew. Energy 2020, 160, 852-864. [CrossRef] 
27. Thygesen, R.; Karlsson, B. Simulation and analysis of a solar assisted heat pump system with two different storage types for high levels of PV electricity self-consumption. Sol. Energy 2014, 103, 19-27. [CrossRef]

28. Nyholm, E.; Goop, J.; Odenberger, M.; Johnsson, F. Solar photovoltaic-battery systems in Swedish households-Self-consumption and self-sufficiency. Appl. Energy 2016, 183, 148-159. [CrossRef]

29. Hanna, R.; Kleissl, J.; Nottrott, A.; Ferry, M. Energy dispatch schedule optimization for demand charge reduction using a photovoltaic-battery storage system with solar forecasting. Sol. Energy 2014, 103, 269-287. [CrossRef]

30. Chen, X.; Wei, T.; Hu, S. Uncertainty-aware household appliance scheduling considering dynamic electricity pricing in smart home. IEEE Trans. Smart Grid 2013, 4, 932-941. [CrossRef]

31. Nottrott, A.; Kleissl, J.; Washom, B. Energy dispatch schedule optimization and cost benefit analysis for grid-connected, photovoltaic-battery storage systems. Renew. Energy 2013, 55, 230-240. [CrossRef]

32. Rahmani-Andebili, M.; Shen, H. Energy scheduling for a smart home applying stochastic model predictive control. In 25th International Conference on Computer Communication and Networks (ICCCN); IEEE: Piscataway, NJ, USA, 2016; pp. 3-8. [CrossRef]

33. Wang, R.; Li, J.; Wang, J.; Gao, C. Research and application of a hybridwind energy forecasting system based on data processing and an optimized extreme learning machine. Energies 2018, 11, 1712. [CrossRef]

34. Bandyopadhyay, S.; Mouli, G.R.C.; Qin, Z.; Elizondo, L.R.; Bauer, P. Techno-Economical Model Based Optimal Sizing of PV-Battery Systems for Microgrids. IEEE Trans. Sustain. Energy 2020, 11, 1657-1668. [CrossRef]

35. Cai, H.; Shen, S.; Lin, Q.; Li, X.; Xiao, H. Predicting the Energy Consumption of Residential Buildings for Regional Electricity Supply-Side and Demand-Side Management. IEEE Access 2019, 7, 30386-30397. [CrossRef]

36. Bhoi, S.K.; Nayak, M.R. Optimal scheduling of battery storage with grid tied PV systems for trade-off between consumer energy cost and storage health. Microprocess. Microsyst. 2020, 79, 103274. [CrossRef]

37. Wu, X.; Hu, X.; Yin, X.; Zhang, C.; Qian, S. Optimal battery sizing of smart home via convex programming. Energy 2017, 140, 444-453. [CrossRef]

38. Dietrich, A.; Weber, C. What drives profitability of grid-connected residential PV storage systems? A closer look with focus on Germany. Energy Econ. 2018, 74, 399-416. [CrossRef]

39. Saber, A.Y.; Venayagamoorthy, G.K. Plug-in vehicles and renewable energy sources for cost and emission reductions. IEEE Trans. Ind. Electron. 2011, 58, 1229-1238. [CrossRef]

40. Fachrizal, R.; Shepero, M.; van der Meer, D.; Munkhammar, J.; Widén, J. Smart charging of electric vehicles considering photovoltaic power production and electricity consumption: A review. eTransportation 2020, 4. [CrossRef]

41. Hoarau, Q.; Perez, Y. Interactions between electric mobility and photovoltaic generation: A review. Renew. Sustain. Energy Rev. 2018, 94, 510-522. [CrossRef]

42. Bhatti, A.R.; Salam, Z.; Aziz, M.J.B.A.; Yee, K.P.; Ashique, R.H. Electric vehicles charging using photovoltaic: Status and technological review. Renew. Sustain. Energy Rev. 2016, 54, 34-47. [CrossRef]

43. Datta, U.; Kalam, A.; Shi, J. Smart control of BESS in PV integrated EV charging station for reducing transformer overloading and providing battery-to-grid service. J. Energy Storage 2020, 28, 101224. [CrossRef]

44. Yong, J.Y.; Ramachandaramurthy, V.K.; Tan, K.M.; Mithulananthan, N. A review on the state-of-the-art technologies of electric vehicle, its impacts and prospects. Renew. Sustain. Energy Rev. 2015, 49, 365-385. [CrossRef]

45. Iqbal, M.N.; Kütt, L.; Lehtonen, M.; Millar, R.J.; Püvi, V.; Rassõlkin, A.; Demidova, G.L. Travel activity based stochastic modelling of load and charging state of electric vehicles. Sustainability 2021, 13, 1550. [CrossRef]

46. Ma, C.T. System planning of grid-connected electric vehicle charging stations and key technologies: A review. Energies 2019, 12 , 4201. [CrossRef]

47. Ahmadian, A.; Mohammadi-Ivatloo, B.; Elkamel, A. A Review on Plug-in Electric Vehicles: Introduction, Current Status, and Load Modeling Techniques. J. Mod. Power Syst. Clean Energy 2020, 8, 412-425. [CrossRef]

48. Wang, Y.; Das, R.; Putrus, G.; Kotter, R. Economic evaluation of photovoltaic and energy storage technologies for future domestic energy systems-A case study of the UK. Energy 2020, 203, 117826. [CrossRef]

49. Yu, H.J.J. System contributions of residential battery systems: New perspectives on PV self-consumption. Energy Econ. 2021, 96, 105151. [CrossRef]

50. Baes, K.; Kolk, M.; Carlot, F.; Merhaba, Y.I.A. Future of Batteries. Available online: https://www.adlittle.com/en/insights/ viewpoints / future-batteries (accessed on 10 July 2021).

51. Dufo-López, R.; Zubi, G.; Fracastoro, G.V. Tecno-economic assessment of an off-grid PV-powered community kitchen for developing regions. Appl. Energy 2012, 91, 255-262. [CrossRef]

52. Numbi, B.P.; Malinga, S.J. Optimal energy cost and economic analysis of a residential grid-interactive solar PV system- case of eThekwini municipality in South Africa. Appl. Energy 2017, 186, 28-45. [CrossRef]

53. Ahmadiahangar, R.; Karami, H.; Husev, O.; Blinov, A.; Rosin, A.; Jonaitis, A.; Sanjari, M.J. Analytical approach for maximizing self-consumption of nearly zero energy buildings- case study: Baltic region. Energy 2022, 238, 121744. [CrossRef]

54. Shabbir, N.; Kütt, L.; Astapov, V.; Jawad, M.; Allik, A.; Husev, O. Battery Size Optimization with Customer PV Installations and Domestic Load Profile. IEEE Access 2022.

55. ELERING Elering. Available online: https:/ / elering.ee/ (accessed on 20 November 2021). 